\title{
Dry Grassland Central Germany Database
}

\author{
Thomas Becker
}

\begin{abstract}
The database of dry grassland vegetation (Festuco-Brometea, Koelerio-Corynephoretea, Calluno-Ulicetea, Psoretea decipientis) in central Germany (Lower Saxony, Saxony-Anhalt, Thuringia) comprises about 2,500 relevés (alliances Alysso-Sedion 103, Armerion elongatae 517, Cirsio-Brachypodion 229, Corynephorion 381, Festucion valesiacae 257, Genistion pilosae 22, Koelerio-Pheion 24, Mesobromion 587, Sedo-Veronicion dillenii 14, Seslerio-Festucion pallentis 113, Thero-Airion 8, Toninion caeruleonigricantis 37, Xerobromion 134). It combines local datasets from own research and other available work in the area of the Hercynian region (in total 8 sources). Beyond classification the database will be used to evaluate and analyse geographic patterns within plant communities. Hosted by the department of Geobotany of the University of Trier, the data are available for collaborative research. This report describes the available content in the Dry Grassland Central Germany Database (GIVD ID EU-DE-034).
\end{abstract}

Keywords: biodiversity; bryophyte; Festuco-Brometea; Koelerio-Corynephoretea; informatics; lichen; phytosociology; soil data; vegetation classification.

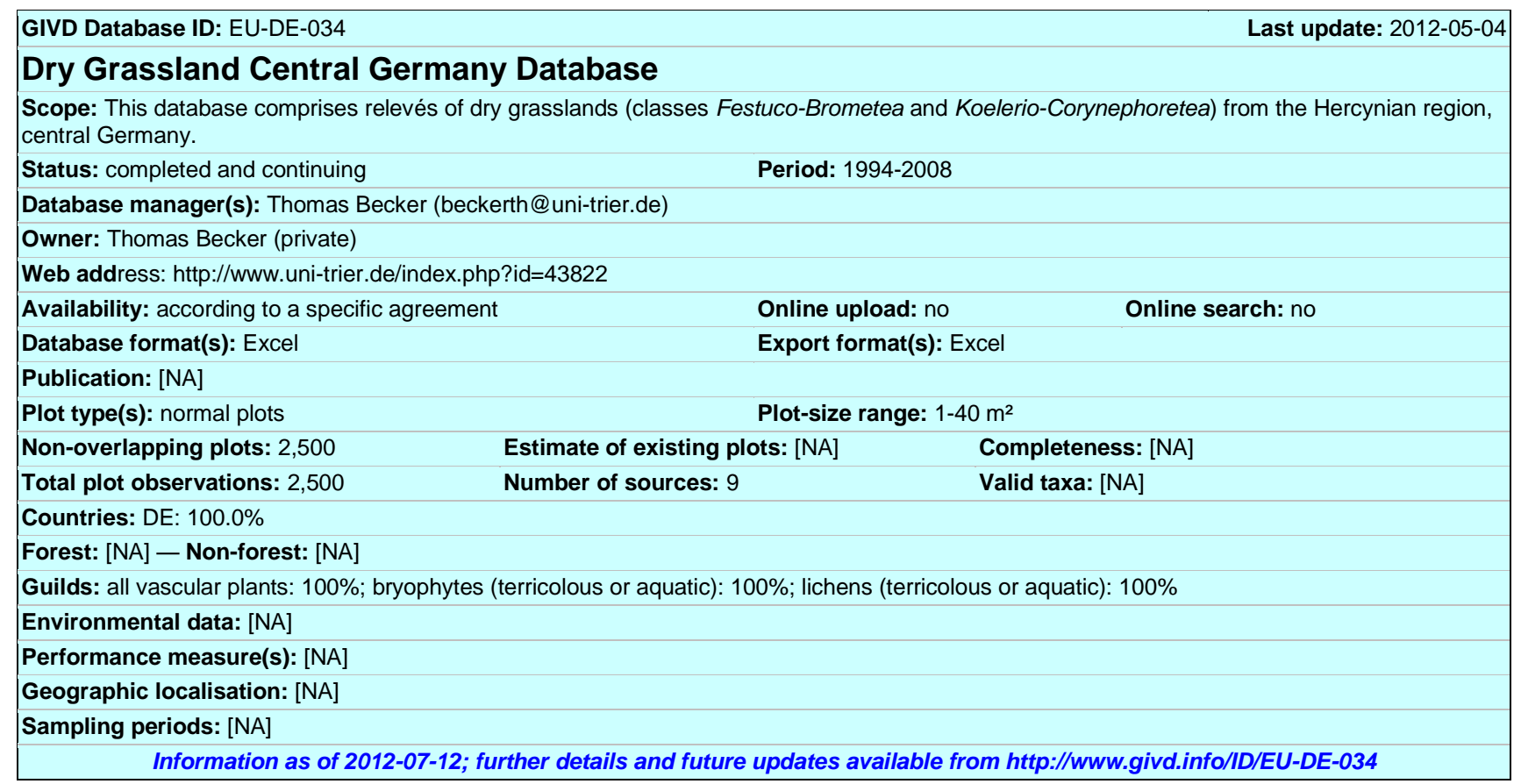

Thomas Becker (beckerth@uni-trier.de)

Department of Geobotany, Faculty of Geography and Geosciences, University of Trier, Behringstr. 21, 54296 Trier, GERMANY 